Jacek Wałdoch

Uniwersytet Gdański

e-mail: jacw@op.pl

\title{
Wybory do Rady Miejskiej i Zarządu Miejskiego miasta Wilna w latach 1905-1913
}

SUMMARY

\section{Vilna Town Council and Board Elections in 1905-1913}

The Town Council elections in Vilna (Vilnius) were conducted on the basis of the Town Act from 1870. This Act increased the amount of councilors and introduced new institutions, such as the Town Council (the Duma), the Board and the Head of the Town.

The election of 1905 resulted in $65 \%$ of new councilors being elected, the majority of whom were Polish. Polish advocate Michał Węsławski, who was supported by the majority of the inhabitants of Vilna, was elected Mayor (President). Due to strikes, which were very common at this time, he started serving as Mayor very late, on November 26th 1905.

The election of 1909 was a little bit different from the previous ones. In particular, the amount of people entitled to vote was increased to 1048, which was almost 800 more than in 1905 . The election took place on May 11th 1909, but because of the protest of Russian electors the Governor decided to annul it and to conduct a new one. It took place on September 9th 1909. In accordance with the earlier decision of the Polish voters, Michał Węsławski was once again elected Mayor.

The next election on October 24th 1913 was preceded by a big election campaign. Polish voters were politically divided into many groups, which presented similar programs and even had the same candidates. The non-partisan committee won the election, taking the majority in the Town Council and Michał Węsławski was elected Mayor for the third time.

Key words: Vilna, Russian Empire, Town Council, elections 
Na terenie Wileńszczyzny, stanowiącej wówczas Kraj Północno-Zachodni Cesarstwa Rosyjskiego, ustawa miejska z 1870 r. weszła w życie w $1876^{1}$, rozszerzając skład samorządów miejskich, w których pojawiło się o wiele więcej radnych niż do tej pory, bo od trzydziestu do siedemdziesięciu dwóch. Ich liczba zależna była od liczby mieszkańców i w miastach, w których nie przekraczała ona trzystu osób, w Radzie zasiadała najniższa liczba radnych. Natomiast w pozostałych miastach rosła ona o sześciu przedstawicieli na każdych kolejnych stu pięćdziesięciu mieszkańców, aż do osiągnięcia maksymalnej liczby deputowanych. Magistraty otrzymały tym samym instytucje w postaci Rady (Dumy) Miejskiej, Zarządu Miejskiego oraz Głowy Miasta. Radni i Głowa Miasta wybierani byli na czteroletnią kadencję, podobnie jak Zarząd, jednak z tą różnicą, że połowa jego członków co dwa lata kończyła kadencję, ale z możliwością reelekcji. Czynne prawo wyborcze opierało się na czterech cenzusach. Przede wszystkim konieczne było posiadanie obywatelstwa rosyjskiego oraz ukończenie dwudziestego piątego roku życia. Po spełnieniu tych dwóch warunków odwoływano się do przesłanek natury majątkowej, czyli „posiadania prawa własności nieruchomości podlegających opodatkowaniu na rzecz miasta", przez co w wyborach brały udział głównie osoby zamożne. Następnie badano, czy wyborcy nie posiadają zadłużenia w opłacie podatków miejskich. Ludność żydowska natomiast została pozbawiona prawa wybierania swoich reprezentantów do Rady Miejskiej².

Zdecydowaną odwilż w relacjach wobec Polaków przyniósł rok 1905, kiedy to przez Imperium Rosyjskie przetoczyła się fala rewolucji, w efekcie której carat zdecydował się na ogłoszenie manifestu z 17 (30) października 1905 r., znacznie liberalizującego dotychczasowe prawo, powodując tym samym złagodzenie przepisów, które dotąd dyskryminowały Polaków m.in. w dostępie do stanowisk administracji publicznej, czy udziału w wyborach do Rady Państwa i Dumy Państwowej ${ }^{3}$. Postanowienia manifestu gwarantowały ludności szereg swobód obywatelskich, charakterystycznych dla ustroju konstytucyjnego, a ponadto Mikołaj II przyznał Dumie Państwowej szersze kompetencje, przez co $\mathrm{z}$ ciała doradczego przekształciła się $\mathrm{w}$ organ prawodawczy i kontrolujący władzę wykonawczą. Potwierdzeniem tego było wydanie ustawy o organizacji ciał prawodawczych, która ukazała się 5 marca (20 lutego) 1906 r. ${ }^{4}$ Zdecydo-

\footnotetext{
I. Jaworski, Zarys dziejów Wilna, Wilno 1929, s. 22.

Gorodowoje położenije wysoczajsze utwerżdennoje 16 (28) ijunija 1870 goda, [w:] Reformy Aleksandra II, red. O. J. Czistiakow, T. E. Nowickaja, Moskwa 1997, s. 235-245.

L. Bazylow, P. Wieczorkiewicz, Historia Rosji, Wrocław 2005, s. 332.

4 J. Sobczak, Mikołaj II - ostatni car Rosji, Warszawa 2009, s. 329-331.
} 
wano się również na utworzenie jednolitej Rady Ministrów na czele z premierem Siergiejem Witte, który przejął inicjatywę scalania tego organu ${ }^{5}$. Jednak najistotniejszą kwestią dla Polaków było przyznanie wolności słowa, sumienia i wyznania ${ }^{6}$, stąd redakcja, pierwszego po powstaniu styczniowym, polskojęzycznego dziennika, „Kuriera Litewskiego”, ogłosiła na łamach swojego pisma, że od 23 października 1905 r. artykuły będą publikowane bez ingerencji cenzury ${ }^{7}$. Natomiast nieco wcześniej, bo już 14 października, grupa radnych wystosowała podanie do prezydenta o rozpatrzenie możliwości używania języka polskiego w urzędzie i wywieszenia szyldów na budynkach użyteczności publicznej z polskimi napisami ${ }^{8}$.

Dla samego Wilna i jego mieszkańców rok 1905 był szczególny ze względu na fakt, że właśnie wtedy miały odbyć się pierwsze wybory do Rady Miejskiej. Były one wyjątkowe, ponieważ mimo niekorzystnego prawa wyborczego wysoka frekwencja pozwoliła na zmianę aż 65\% dawnego składu Rady. Czynne prawo wyborcze posiadało jedynie trzysta osób na sto osiemdziesiąt tysięcy mieszkańców Wilna, więc tak niewiele osób musiało zadecydować za większość wileńskiej społeczności. Redaktor „Kuriera Litewskiego” pisał nawet o swoistym „zamachu stanu", jakiego dokonała ta nieduża grupa mieszkańców, wybierając swoich sześćdziesięciu czterech reprezentantów. Wśród nich znalazło się dwudziestu pięciu urzędników, dwunastu lekarzy, dziewięciu obywateli miejskich z racji posiadania wielu nieruchomości, ośmiu kupców, ośmiu inżynierów i techników, trzech rzemieślników, dwóch nauczycieli oraz dwóch prawników. W Radzie zasiedli zatem przedstawiciele narodowości polskiej i rosyjskiej, reprezentujący prawie wszystkie szanowane profesje, jednak skład ten miał zostać dopełniony ze względu na brak w nim środowiska żydowskiego. Kandydatem na prezesa Rady i Zarządu został adwokat przysięgły Michał Węsławski, mający zastąpić ustępującego prezydenta Pawła Bertholdta. Zarząd miasta Wilna miał zostać powołany przez Radę niedługo po tym i w jego skład musiało wejść aż sześć osób, aby podejmowanie decyzji miało charakter demokratyczny, a nie, jak to miało miejsce do tej pory, autorytarny9.

Pierwsze posiedzenie nowej Rady Miejskiej odbyło się 3 września 1905 r., a otworzył je gubernator wileński, hrabia Konstanty von der Pahlen. Podczas swojego wystąpienia wyjaśnił radnym zależność pomiędzy władzami gubernialnymi a Zarządem Miejskim. Stwierdził, że te pierwsze pełnią podwójną funkcję:

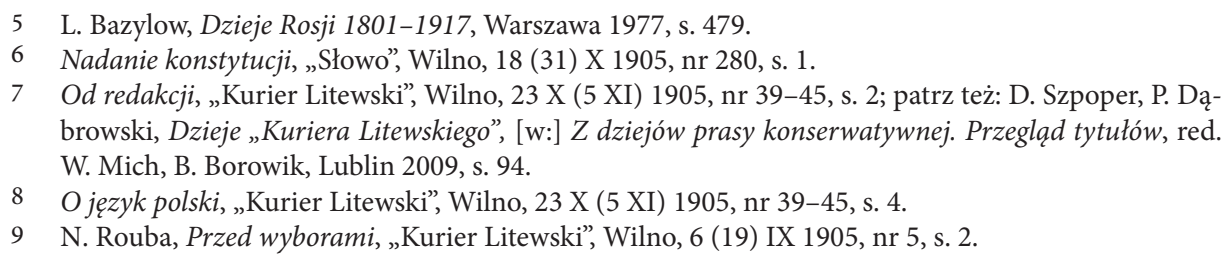


po pierwsze, są „hamulcem” dla decyzji organów miejskich, które nie zostały wystarczająco dobrze przygotowane, a po drugie, są „źródłem” w poszukiwaniu odpowiednich rozwiązań dla obywateli Wilna. W dalszej części posiedzenia głos zabrał generał Paweł Bertholdt - prezydent miasta, który powitał nowych radnych i życzył im „owocnej działalności”, po czym przystąpił do omawiania spraw zgodnie z planem obrad. Zadecydowano wtedy, że konieczne jest wybudowanie baraku dla osób chorych lub podejrzanych o zakażenie cholerą, która w tamtym okresie zbierała śmiertelne żniwo wśród mieszkańców miast. Specjalny barak miał stanąć przy szpitalu dziecięcym w dzielnicy Wilna - Zwierzyńcu, dzięki czemu sama placówka wzbogaciłaby się o kolejne pomieszczenie, gdyby epidemia jednak nie objęła miasta ${ }^{10}$.

Prezydenta Wilna wybrała Rada Miejska na posiedzeniu 21 września $1905 \mathrm{rr}^{11}$, a funkcję tę objął Michał Węsławski ${ }^{12}$, którego kandydatura od początku nie budziła żadnych wątpliwości. Wybory na to stanowisko i tym samym na prezesa Rady odbyły się 21 września 1905 r. Jednocześnie powołano dwóch członków Zarządu Miejskiego - Mieczysława Malinowskiego i Aleksandra Łapińskiego, rezygnując z sześcioosobowego składu Zarządu ${ }^{13}$. Były to o tyle ważne wybory, że po raz pierwszy od czterdziestu trzech lat prezydentem miasta został Polak $^{14}$, a do tego osoba godna powierzonych mu zadań i ciesząca się poparciem większości wilnian. Ówczesny skład Rady i Zarządu miał wyglądać następująco: prezes Rady w osobie prezydenta, dwóch członków Zarządu, sekretarz oraz członek - delegat rady do Gubernialnego Zarządu dla Spraw Miejskich.

Październik był dla mieszkańców Wilna okresem szczególnie niebezpiecznym, pełnym zamieszek, zabójstw i innych aktów przemocy, które ogarnęły cały kraj. Zarząd miasta Wilna w obliczu tych dramatycznych wydarzeń zwołał 20 października 1905 r. specjalne posiedzenie, na które zaprosił przedstawicie-

10 Kronika krajowa. Pierwsze posiedzenie..., „Kurier Litewski”, Wilno, 3 (16) IX 1905, nr 3, s. 2.

11 Nowy prezydent, „Kurier Litewski”, Wilno, 21 IX (4 X) 1905, nr 17, s. 2

12 Michał Węsławski urodził się 4 września 1849 r. w majątku Gegrany, w powiecie telszewskim, guberni kowieńskiej. Po odbyciu nauki w gimnazjum rozpoczął edukację na wydziale prawa uniwersytetu petersburskiego, który ukończył otrzymując stopień kandydata nauk prawnych. Przez kolejne dwa lata, czyli do 1876 r. odbywał aplikację sądową, a w 1877 r. objął stanowisko sędziego śledczego I rewiru miasta Kiszyniowa. Po śmierci swojego brata porzucił dotychczasową pracę i przeniósł się do Wilna, gdzie w 1879 r. mianowano go adwokatem przysięgłym izby sądowej okręgu wileńskiego. Dzięki swojej pracy stał się człowiekiem rozpoznawanym, a przez działalność publiczną oraz członkostwo w Towarzystwie Rolniczym zyskał szacunek społeczności lokalnej. Pierwszym tego dowodem było powołanie go na stanowisko prezesa komisji adwokatów przysięgłych, a zdanie wilnian zostało później potwierdzone w wyborach miejskich, patrz: Nowy prezydent...; patrz też: P. Dąbrowski, Siła w kulturze, jedność w narodzie. Wileńska działalność społeczno-polityczna Michała, Witolda i Emilii Węsławskich końcu XIX wieku i pierwszej połowie XX stulecia (do 1930 roku), Gdańsk 2011, s. $15-22$.

13 Nowy prezydent...

14 Kronika krajowa. Z Rady miejskiej, „Kurier Litewski”, Wilno, 26 XI (9 XII) 1905, nr 73, s. 2. 
li wszystkich klas społecznych, ugrupowań politycznych, towarzystw i wyznań. Nadal urzędujący prezydent Wilna Paweł Bertholdt rozpoczął zebranie, wyjaśniając jego cel. Zarząd potrzebował porady w kwestiach rozwiązania tej niekorzystnej dla miasta sytuacji, a przynajmniej złagodzenia lub zmniejszenia jej negatywnych skutków, które w szczególny sposób dotykały mniej zamożnych obywateli Wilna. Rozmowy były na tyle owocne, że zebrani doszli do szybkiego porozumienia. Uchwalono m.in. powołanie dwunastoosobowej komisji, mającej przeprowadzić śledztwo dotyczące ostatnich wydarzeń oraz wyłonienie komitetu zbierającego składki na rzecz osób żyjących w ubóstwie z powodu mających miejsce strajków ${ }^{15}$.

25 października dobiegały one końca. Przez ostatnie dni do Wilna nie dochodziły wcale, albo w bardzo ograniczonym zakresie, transporty $\mathrm{z}$ artykułami spożywczymi z okolicznych gospodarstw rolnych, a to w obawie przed napaściami i kradzieżami. Konieczne stało się poinformowanie mieszkańców wsi, że droga do miasta jest już bezpieczna. W artykule w „Kurierze Litewskim” pojawiła się propozycja utworzenia w dni targowe (wtorek i sobota) straży targowej, która miałaby pilnować porządku na rogatkach miasta ${ }^{16}$. Sytuacja $\mathrm{w}$ mieście była jednak jeszcze na tyle napięta, że 1 listopada 1905 r. Rada Miejska powołała Komitet Bezpieczeństwa. Organ ten miał być „[...] łącznikiem między mieszkańcami, a administracją, dla wynalezienia sposobów przywrócenia spokoju w mieście”. Składać się miał z komitetu centralnego z trzynastoma członkami i ośmiu podkomitetów z siedmioma jego przedstawicielami, wybieranymi przez Radę Miejską. Komitetowi przyznano dość szerokie kompetencje, mógł nawet sprawować kontrolę nad czynnościami policji. W gruncie rzeczy jego praca polegać miała głównie na zbieraniu informacji o potencjalnych zagrożeniach, przekazywaniu ich odpowiednim organom oraz działalności opiniotwórczej, w celu „przywrócenia spokoju"17. Jednak ta koncepcja swoistej milicji miejskiej nie została sfinalizowana $\mathrm{z}$ uwagi na brak poparcia ze strony gubernatora, który nie wyraził zgody na używanie broni przez członków tej służby, mimo że w innych miastach było to praktykowane ${ }^{18}$. Prace nad utworzeniem milicji trwały dalej i ustalono, że miałaby ona pełnić straż równolegle z policją, jednak w godzinach nocnych od godziny dziewiętnastej do siódmej rano ${ }^{19}$. Niestety, już 24 listopada prasa ogłosiła, że idea utworzenia milicji została zawieszona do odwołania ${ }^{20}$.

Wydarzenia te opóźniły o ponad miesiąc faktyczne przejęcie władzy nad miastem przez prezydenta Węsławskiego, który przewodniczenie Radzie objął

15 Wobec manifestu, „Kurier Litewski”, Wilno, 23 X (5 XI) 1905, nr 39-45, s. 2.

16 Kronika krajowa, „Kurier Litewski”, Wilno, 25 X (7 XI) 1905, nr 46, s. 2.

17 Kronika krajowa, „Kurier Litewski”, Wilno, 1 (14) XI 1905, nr 52, s. 2.

18 Kronika krajowa. Milicja miejska, „Kurier Litewski”, Wilno, 13 (26) XI 1905, nr 62, s. 4.

19 Kronika krajowa, „Kurier Litewski”, Wilno, 19 XI (2 XII) 1905, nr 67, s. 2.

20 Kronika krajowa. Milicja miejska, „Kurier Litewski”, Wilno, 24 XI (7 XII) 1905, nr 71, s. 2. 
dopiero 26 listopada 1905 r. Oficjalne powitanie wygłosił dr Restytut Sumorok słowami: „Panie Prezydencie, witamy Pana, jako pierwszego Prezydenta Polaka, po latach 43-ech. Zaznaczając ten fakt doniosły, jako pierwszy krok na drodze zdobycia praw i równouprawnienia narodowego na Litwie, wierzymy, że razem z Panem rozpoczynamy pracę pożyteczną dla społeczeństwa i zdobywając nowe prawa, idziemy ku lepszej, jaśniejszej przyszłości”21. Natomiast pierwsze merytoryczne posiedzenie Rady pod przewodnictwem Węsławskiego odbyło się 2 grudnia 1905 r. Uczestniczyło w nim pięćdziesięciu pięciu radnych, którzy poruszyli cztery istotne dla miasta sprawy. Przede wszystkim wybrano wiceprezydenta Wilna, którym został Mieczysław Malinowski, zdobywając poparcie czterdziestu trzech głosujących. Ponadto uchwalono podniesienie wynagrodzenia dla funkcjonariuszy straży pożarnej. Rozpatrzono również kwestię wywłaszczenia dwustu czterdziestu dwóch sążni ${ }^{22}$ należących do Towarzystwa Taniej Kuchni dla Żydów miasta Wilna w celu poszerzenia dwóch ulic. Postanowiono powołać specjalną komisję, która zajęłaby się załatwieniem tej sprawy za obopólną zgodą ${ }^{23}$.

Urzędnicy miejscy, idąc za przykładem innych grup społecznych, postanowili powołać własną organizację o nazwie Związek Inteligentnych Pracowników Zarządu Miejskiego w Wilnie. 2 grudnia 1905 r. wybrano prezesa Rady Związku w osobie Wacława Michniewicza i jego zastępcę - Karola Niekrasza. Do Związku przystąpiło w tym dniu sto dwanaście osób, zaś takiej decyzji nie podjęło dwudziestu dwóch pracowników, więc należałoby sądzić, że w pierwszych dniach grudnia 1905 r. wileński magistrat liczył około stu trzydziestu czterech urzędników ${ }^{24}$. Warto wspomnieć, że wybór prezydenta przez obywateli miasta nie był ostateczny, ponieważ jego kandydatura mogła spotkać się z vetem gubernatora wileńskiego. Uszanował on jednak wolę mieszkańców miasta, konsultując się z władzami w Sankt Petersburgu, które były przychylne Węsławskiemu. Chciano tym samym przyspieszyć ukonstytuowanie się nowych władz miejskich, które mogłyby opanować wyjątkowo skomplikowaną sytuację panującą w mieście ${ }^{25}$.

Do wyborów miejskich w 1909 r. Rada Miejska przygotowywała się od pierwszego miesiąca nowego roku i na posiedzeniu, już 8 stycznia, zajęto się sprawą podstawową, dotyczącą organizacji wyborów. Pojawił się bowiem projekt, aby przeprowadzić je w ciągu dwóch dni, jednak radni, znając ówczesne realia, jednomyślnie stwierdzili, że wystarczy jedno zebranie wyborcze. Podyktowane było

21 Kronika krajowa. Z Rady miejskiej, „Kurier Litewski”, Wilno, 26 XI (9 XII) 1905, nr 73, s. 2.

221 sążeń rosyjski $=2,13 \mathrm{~m}$.

23 Kronika krajowa. Z Rady miejskiej, „Kurier Litewski”, Wilno, 2 (15) XII 1905, nr 78, s. 2.

24 Kronika krajowa. Związek pracowników zarządu miejskiego, „Kurier Litewski”, Wilno, 10 (23) XII 1905 , nr 85, s. 2.

25 Kronika krajowa, „Kurier Litewski”, Wilno, 9 (22) XI 1905, nr 58, s. 3; patrz też: Kronika krajowa, „Kurier Litewski”, Wilno, 26 XI (9 XII) 1905, nr 73, s. 2. 
to tym, że frekwencja nie będzie wymagała rozkładania głosowania na kolejny dzień, ponieważ obliczono, że liczba wyborców nie przekroczy tysiąca stu sześćdziesięciu osób ${ }^{26}$, a ponadto dwudniowe głosowanie wiązałoby się z trudnościami technicznymi i dodatkowymi kosztami dla miasta ${ }^{27}$. Miesiąc później Zarząd Miejski opublikował listę tysiąca dziewiętnastu nazwisk osób, posiadających czynne prawo wyborcze. Wskazano, że powinny one sprawdzić, czy nadal spełniają warunki cenzusu majątkowego, a jeżeli ktoś na liście się nie znalazł, a uważał, że może wziąć udział w wyborach, to powinien złożyć odpowiednią deklarację w ciągu dwóch tygodni, licząc od 5 lutego ${ }^{28} .13$ lutego 1909 r. w „Kurierze Litewskim" pojawił się artykuł informujący obywateli Wilna o możliwości uczestnictwa w wyborach za pośrednictwem swojego pełnomocnika. W tym zakresie prawo również przewidywało pewne obostrzenia. W imieniu kobiet $\mathrm{w}$ wyborach mogli brać udział ich ojcowie, mężowie, synowie, zięciowie, wnukowie, rodzeni bracia oraz siostrzeńcy. Ojciec natomiast mógł dać pełnomocnictwo tylko swojemu synowi, o ile ten z nim zamieszkiwał. Natomiast w przypadku pełnoletnich mężczyzn, którzy nie ukończyli dwudziestego piątego roku życia, w ich imieniu głos mogła oddać wskazana osoba, pod warunkiem, że sama dysponowała prawem wyborczym. Prawo do bycia pełnomocnikiem odebrano jednak Żydom ${ }^{29}$. Co ciekawe, w wyborach mogły brać udział spółki, towarzystwa i inne instytucje, a ich przedstawicielem mogła być osoba niespełniająca cenzusu majątkowego. Zarząd zobligowany był do wcześniejszej weryfikacji danych, przedstawionych w pełnomocnictwie, dlatego musiało ono być dodatkowo uwierzytelnione przez przełożonego osoby upełnomocniającej, jeżeli ta była na służbie, a w innych przypadkach przez policję, sędziego pokoju albo notariusza. W nieco lepszej sytuacji był pełnomocnik instytucji, który musiał okazać pełnomocnictwo potwierdzone jedynie przez Zarząd. Według przepisów ustawy miejskiej mieszkaniec miasta, który ponad pół roku nie wywiązywał się ze swojego obowiązku podatkowego automatycznie tracił prawo udziału w wyborach miejskich. Liczba zgłaszających się wileńskich wyborców systematycznie rosła i do 13 lutego wyniosła tysiąc dziewięćdziesiąt i jedna osoba ${ }^{30}$.

Po zamknięciu listy osób uprawnionych do oddania głosu, przekazano ją gubernatorowi do zatwierdzenia i opublikowania w gubernialnych „Wiedomostiach", co wiązało się z zakazem dokonywania później jakichkolwiek zmian w spisie wyborców. W Wilnie Zarząd Miejski wskazał tysiąc pięćdziesięciu jeden wyborców, co pozwalało na określenie liczby przyszłych radnych, których w składzie Rady miało znaleźć się siedemdziesięciu siedmiu. Zależało to jeszcze

26 Z rady miejskiej, „Goniec Wileński”, Wilno, 9 (22) I 1909, nr 6, s. 3.

27 K. P. [sygn. nierozwiązana], W radzie miejskiej, „Kurier Litewski”, Wilno, 10 (23) I 1909, nr 7, s. 3.

28 Kronika Wileńska. Wybory miejskie, „Kurier Litewski”, Wilno, 7 (20) II 1909, nr 30, s. 2.

29 Kronika Wileńska. Ograniczenia dla Żydów, „Kurier Litewski”, Wilno, 1 (14) I 1909, nr 1, s. 4.

30 Kronika Wileńska. Wybory miejskie, „Kurier Litewski”, Wilno, 13 (26) II 1909, nr 35, s. 2. 
od informacji na temat osób, które zalegają z zapłaceniem podatku miejskiego, ponieważ traciły one ex lege prawo wyborcze, jeżeli nie uiściły opłaty przed ogłoszeniem ostatecznej listy wyborczej. W Wilnie dotyczyło to osiemnastu osób, co dawałoby zmniejszenie liczby radnych o trzy osoby ${ }^{31}$. Był to z pewnością czynnik motywujący obywateli do uregulowania spraw podatkowych, jednak trzy osoby nie dokonały tej czynności. Spowodowało to, że liczba wyborców wyniosła tysiąc czterdzieści osiem osób, co dawało Wilnu siedemdziesięciu czterech ${ }^{32}$ radnych, z których wyborowi podlegało sześćdziesiąt siedem osób ${ }^{33}$. Radnymi mogli być również Żydzi, jednak byli oni mianowani przez gubernatora $\mathrm{w}$ liczbie ustalanej przez ministra spraw wewnętrznych, z zastrzeżeniem, że nie może ona przekroczyć $10 \%$ składu Rady ${ }^{34}$. W kwietniu gubernator przewidział dla nich sześć miejsc w Radzie Miejskiej ${ }^{35}$. Pod koniec miesiąca Ministerstwo Spraw Wewnętrznych pouczyło w tej sprawie gubernatora wileńskiego, że dla zapewnienia odpowiedniej liczby miejsc dla Żydów należy wykreślić kandydatów, którzy zdobyli najmniej głosów ${ }^{36} .25$ marca 1909 r. lista wyborców była już zatwierdzona przez gubernatora, a termin głosowania ustalono na poniedziałek, 11 maja 1909 r., od godziny jedenastej do szesnastej ${ }^{37}$, w sali miejskiej przy ulicy Ostrobramskiej $10^{38}$. Pod koniec kwietnia Zarząd Miejski określił dokładny program wyborów, a mianowicie, w dniach: 12, 13 i 14 maja odbyć się miało liczenie głosów, a w trakcie kolejnych trzech dni „balotowanie gałkami kandydatów zaproponowanych", czyli ostateczny wybór osób poprzez oddawanie głosu za pomocą czarnych i białych kulek. Aby przejść do tego etapu, należało zdobyć pięć głosów w pierwszym dniu wyborów ${ }^{39}$.

W marcu 1909 r. już na dobre rozpoczęła się kampania wyborcza. Co prawda w Wilnie nie działały typowe partie polityczne, jednak wyborcy wyraźnie podzielili się na grupy proponujące program planowanych działań, dotyczących miasta oraz swoich kandydatów na radnych. Powstały dwie „partie” wyborcze: „partia bloku” i grupa demokratyczna wyborców miejskich ${ }^{40}$. Nazwy pierwszej formacji jeszcze nie znano albo jej nie posiadała, ale określono ją również

31 Wybory do rady miejskiej, „Goniec Wileński”, Wilno, 11 (24) III 1909, nr 56, s. 1.

32 W maju 1909 r. „Kurier Litewski” podał, że wybranych zostanie 75 radnych, patrz: Kronika Wileńska. Wybory miejskie, „Kurier Litewski”, Wilno, 10 (23) V 1909, nr 104, s. 2.

33 Kronika Wileńska. Wybory miejskie, „Kurier Litewski”, Wilno, 15 (28) III 1909, nr 60, s. 8.

34 Wybory do rady miejskiej, „Goniec Wileński”, Wilno, 11 (24) III 1909, nr 56, s. 1.

35 Kronika Wileńska. Wybory miejskie, „Kurier Litewski”, Wilno, 9 (22) IV 1909, nr 78, s. 2.

36 Kronika Wileńska. Wybory miejskie, „Kurier Litewski”, Wilno, 26 IV (9 V) 1909, nr 93, s. 2.

37 Kronika Wileńska. Wybory miejskie, „Kurier Litewski”, Wilno, 29 IV (12 V) 1909, nr 95, s. 2; patrz też: Wybory miejskie, „Kurier Litewski”, Wilno, 2 (15) V 1909, nr 98, s. 2, gdzie podano inne godziny głosowania, bo od 11 do 17, oraz dni trwania wyborów od 11 do 19 maja.

38 Kronika Wileńska. Wybory miejskie, „Kurier Litewski”, Wilno, 25 III (7 IV) 1909, nr 68, s. 3.

39 Kronika Wileńska, „Kurier Litewski”, Wilno, 13 (26) V 1909, nr 106, s. 2.

40 Rochita [sygn. nierozwiązana], Z powodu wyborów miejskich, „Goniec Wileński”, Wilno, 17 (30) III 1909, nr 61, s. 1-2. 
mianem „obozu bezpartyjnego" ${ }^{11}$. Wiadomo jedynie, że obie grupy reprezentowały podobne poglądy i proponowały de facto identyczne rozwiązania, dbając przede wszystkim o dobro Wilna, szczególnie w zakresie municypalizacji przedsiębiorstw miejskich. Można również sądzić, że grupa bezpartyjna powiązana była $z$ demokratycznym nurtem krajowym poprzez przewodniczącego Adolfa Zmaczyńskiego ${ }^{42}$. Natomiast grupę demokratyczną należałoby łączyć z obozem narodowo-demokratycznym (endecją), ze względu na działalność polityczną przewodniczącego, margrabiego Bronisława Umiastowskiego ${ }^{43}$.

Jeden z członków grupy demokratycznej wyborców, używający pseudonimu Rochita, przedstawił na łamach „Gońca Wileńskiego" projekt konsensusu, który polegał na wspólnym przygotowaniu list nazwisk kandydatów na radnych. Dwie grupy polskich wyborców miałyby wybrać spośród siebie dwie - cztery osoby, które zaprosiłyby na zebranie wszystkich wyborców Polaków. Na nim powołany komitet, składający się z piętnastu - dwudziestu członków, przygotowałby program dla przyszłej Rady Miejskiej oraz wykaz proponowanych kandydatów. Na kolejnym spotkaniu miałoby dojść do ich zatwierdzenia, z możliwością zaproponowania innych nazwisk, po czym wszyscy wyborcy zobowiązaliby się do głosowania na z góry wskazanych obywateli. Miało to zablokować "tych trzecich” i sprawić, że stanowiska w Radzie Miejskiej obsadzone byłyby głównie przez Polaków ${ }^{44}$.

Można sądzić, że kłóciło się to nieco z wcześniejszym oświadczeniem, że polscy wyborcy są za tym, aby każda narodowość miała w Radzie swoich przedstawicieli, proporcjonalnie do swojej wielkości. Jak widać, Polacy obawiali się grupy rosyjskich wyborców, dlatego w programie jednej z polskich grup znalazły się popularne postulaty, których celem było przyciągnięcie większej rzeszy ich zwolenników. W zakresie funkcjonowania Rady Miejskiej określono zadania dla nowych radnych, którzy przede wszystkim więcej uwagi mieli poświęcać innym dzielnicom miasta, nie tylko Śródmieściu. Zaproponowano też m.in. jawność posiedzeń przyszłej Rady, obniżenie cenzusu majątkowego w wyborach, odebranie radnym możliwości obsadzania płatnych stanowisk przy Zarządzie oraz licytacyjny charakter zamówień publicznych. Ponadto chciano postawić na wielokulturową edukację w szkołach, utworzenie uniwersytetu, muzeum i biblioteki miejskiej, budowę kanalizacji i wodociągów, których brak mocno dawał się

41 Red., Wybory miejskie, „Goniec Wileński”, Wilno, 18 IV (1 V) 1909, nr 86, s. 2.

42 Kronika Wilenska. Komitet grupy wyborców..., „Kurier Litewski”, Wilno, 13 (26) V 1909, nr 106, s. 2; patrz też: P. Dąbrowski, Narodowa Demokracja byłego Wielkiego Księstwa Litewskiego. Studium z zakresu myśli politycznej i działalności obozu narodowego na ziemiach litewsko-białoruskich $w$ latach 1897-1918, Kraków 2010, s. 49.

43 P. Dąbrowski, op. cit., s. 49, 57; patrz też: Wybory do Rady miejskiej, „Goniec Wileński”, Wilno, 6 (19) V 1909, nr 101, s. 2.

44 Rochita [sygn. nierozwiązana], Z powodu wyborów miejskich., „Goniec Wileński”, Wilno, 17 (30) III 1909, nr 61, s. 1-2. 
we znaki mieszkańcom i niewątpliwie miał wpływ na sytuację sanitarną miasta. Wiele miejsca poświęcono także tematowi tramwajów elektrycznych jako środka transportu niezbędnego w rozwijającym się mieście ${ }^{45}$.

Kwiecień 1909 r. stał się miesiącem wytężonej pracy wszystkich grup politycznych i okresem decydującym o wyniku nadchodzących wyborów do Rady Miejskiej. Okazało się, że pomysł przedstawiony przez Rochitę został zaaprobowany przez polskich wyborców. Niestety, nad realizacją tego projektu każda z grup pracowała oddzielnie. W skład tzw. grupy demokratycznej wchodziło ponad stu członków, a ich pierwsze zebranie odbyło się 19 kwietnia, na którym ustalono program działania przyszłej rady, wybrano komitet wyborczy oraz przygotowano listę dziewięćdziesięciu jeden ${ }^{46}$ kandydatów na radnych. Każdy z wyborców musiał uznać listę, składając na niej swój podpis, jako zobowiązanie do głosowania na wskazaną osobę ${ }^{47}$. Drugi obóz wyborczy, prawdopodobnie bezpartyjny, opublikował listę swoich kandydatów w prasie, co odbiło się echem wśród demokratycznej grupy wyborczej, która na łamach „Gońca Wileńskiego” wyraziła swoje niezadowolenie wobec działań konkurencji wyborczej, stwierdzając, że liczyli ciągle na porozumienie i połączenie obu grup ${ }^{48}$. Niewątpliwie był to zabieg propagandowy, ponieważ do tej pory żaden z komitetów wyborczych nie próbował nawiązać współpracy z przeciwnikami, a dokonanie tego sześć dni przed terminem wyborów było po prostu nierealne. Co więcej, w opublikowanej przez nich liście kandydatów w liczbie dziewięćdziesięciu trzech, można było znaleźć wiele takich samych nazwisk, jak na liście konkurencyjnej ${ }^{49}$.

Bez wątpienia okres wyborczy był dla mieszkańców Wilna czasem szczególnym, bowiem ważyły się przyszłe losy miasta i ich samych. W ciągu trzech dni mieli zdecydować, kto wejdzie w skład Rady Miejskiej i jednocześnie, kto przez najbliższe cztery lata będzie pracował dla dobra wileńskiej społeczności, spełniając przedwyborcze obietnice. Oczywiście nikt chyba nie miał wtedy wątpliwości, że plany budowy kanalizacji, wodociągów, gazowni, czy linii tramwajowej nie są do zrealizowania w ciągu krótkiego czasu kadencji. Nie dość, że było to niewykonalne technicznie, to bardziej obawiano się nieudolności nowego składu Rady Miejskiej. Otóż tzw. grupa demokratyczna zaproponowała listę kandydatów na radnych, których nazwiska były mało znane ogółowi mieszkańców, a co więcej, niemały procent $z$ nich nie miał żadnego doświadczenia w zarządzaniu miastem. Rodziły się słuszne obawy, że nowo wybrany skład przedstawicieli wilnian nie poradzi sobie z postawionym przed nim wyzwaniem. Ten sam komitet wybor-

45 Program grupy demokratycznej wyborców miejskich, „Goniec Wileński”, Wilno, 19 III (1 IV) 1909, nr 63, s. 1-2.

46 Wybory do rady miejskiej, „Goniec Wileński”, Wilno, 1 V (14 V) 1909, nr 97, s. 2; patrz też: Kronika Wileńska. Akcja wyborcza do Rady miejskiej, „Kurier Litewski”, Wilno, 22 IV (5 V) 1909, nr 89, s. 2.

47 Akcja wyborcza do rady miejskiej, „Kurier Litewski”, Wilno, 22 IV (5 V) 1909, nr 89, s. 2.

48 Wybory do rady miejskiej, „Goniec Wileński”, Wilno, 5 V (18 V) 1909, nr 100, s. 2.

49 Wybory miejskie, „Kurier Litewski”, Wilno, 6 (19) V 1909, nr 101, s. 2. 
czy zaproponował ponadto całkowitą zmianę personalną w Zarządzie Miejskim oraz w komisjach wykonawczych i projektodawczych, jednak było już za późno na próby uświadamiania obywateli - machina wyborcza ruszyła ${ }^{50}$.

Należy pamiętać, że agitacją wyborczą zajmowali się nie tylko Polacy, ale również dwa rosyjskie komitety wyborcze ${ }^{51}$, z których jeden zaproponował swoją listę czterdziestu dwóch kandydatów do Rady Miejskiej, twierdząc, że w obecnym stanie rzeczy Rosjanie pozbawieni są prawa głosu, jeżeli chodzi o sprawy Wilna. Zwrócili oni również uwagę, że „obecny skład Rady uprawia nacjonalistyczno - szowinistyczną politykę i dąży do spolszczenia miasta”. Wprost apelowali do rosyjskich wyborców, aby wzięli udział w głosowaniu i białe kulki przyznali wyłącznie kandydatom wymienionym na liście ${ }^{52}$.

15 maja komisja wyborcza poinformowała, że zakończyła liczenie głosów, w związku z czym można było przejść do kolejnego, ostatecznego etapu wyborów. Zauważono, że balotowaniu poddani zostaną wszyscy kandydaci, zaproponowani przez komitety polskie i rosyjski oraz osoby spoza tych list, jak np. były prezydent Wilna, generał Paweł Bertholdt ${ }^{53}$.

Głosowanie przy pomocy kulek zainaugurował prezydent miasta Michał Węsławski, odczytując najpierw odpowiednie przepisy, stanowiące podstawę prawną dla organizacji wyborów, a następnie zwrócił się z prośbą do kandydatów, aby potwierdzili, że chcą brać udział w tej turze wyborów. Zrezygnowały wówczas w sumie cztery osoby. Przystąpiono dalej do oddawania głosów na przyszłych radnych, których podzielono na dwanaście grup, mniej więcej po piętnaście osób w każdej, aby ułatwić pracę komisji wyborczej ${ }^{54}$. Tego dnia wybrano w sumie pięćdziesięciu czterech radnych, wśród których było niewielu zaproponowanych przez komitet demokratyczny, który poniósł klęskę, podobnie jak kolejnego dnia ${ }^{55}$.

Po zakończeniu wyborów emocje wśród społeczeństwa wyraźnie opadły, ponieważ nie sprawdził się czarny scenariusz i wyborów nie wygrał wyżej wspomniany obóz demokratyczny. Prezydent Węsławski, zapytany o wrażenia i ocenę wyborów, stwierdził, że był zadowolony z wyników głosowania ze względu na fakt, że w Radzie Miejskiej zasiądą w dużej mierze osoby doświadczone. Pozytywnym aspektem, według niego, było również to, że Rada wzbogaciła się o wszystkie narodowości, zamieszkujące Wilno, a także o reprezentantów przedmieść, którzy wcześniej nie posiadali wyraźnego przedstawicielstwa, przez co ich miejsce zamieszkania było pomijane m.in. w inwestycjach miejskich ${ }^{56}$.

50 L. Abramowicz, Kto zwycięży?, „Kurier Litewski”, Wilno, 13 (26) V 1909, nr 106, s. 2.

51 Związkowcy i wybory miejskie, „Goniec Wileński”, Wilno, 5 (18) VII 1909, nr 149, s. 1-2.

52 Agitacja „istinno-russkich”, „Kurier Litewski”, Wilno, 14 (27) V 1909, nr 107, s. 2.

53 Kronika Wileńska. Wybory miejskie, „Kurier Litewski”, Wilno, 15 (28) V 1909, nr 108, s. 2.

54 Kronika Wileńska. Wybory miejskie, „Kurier Litewski”, Wilno, 16 (29) V 1909, nr 109, s. 2.

55 Kronika Wileńska. Wybory miejskie, „Kurier Litewski”, Wilno, 17 (30) V 1909, nr 110, s. 4.

56 Po wyborach, „Kurier Litewski”, Wilno, 20 V (2 VI) 1909, nr 111, s. 2. 
Pojawił się jednak inny, o wiele poważniejszy problem, ponieważ zaprotestowała niezadowolona $\mathrm{z}$ wyborów grupa rosyjska, tzw. związkowcy. Powodem był fakt, że żaden $\mathrm{z}$ zaproponowanych przez nich kandydatów nie dostał się do składu Rady Miejskiej, co skłoniło ich do wniesienia skarg do gubernatora na przeprowadzone wybory ${ }^{57}$. Główne zastrzeżenia dotyczyły maszyny do balotowania ${ }^{58}$, kontroli oraz podziału na grupy podczas balotażu. Wyjaśnienie Zarządu Miejskiego w Urzędzie Gubernialnym do Spraw Miejskich ${ }^{59}$, że automaty używane do głosowania zatwierdzone zostały przez Ministerstwo Spraw Wewnętrznych, nie odniosły skutku. Zepsuł się tylko jeden, jednak po jego usunięciu powtórzono głosowanie na działającej maszynie ${ }^{60}$. Ponadto organizacja poprzednich wyborów niczym nie różniła się od tych z 1909 r., a wtedy nie wniesiono żadnych zastrzeżeń. Argumenty te okazały się być jednak niewystarczające i Urząd poprosił o szczegółowe wyjaśnienia w tej sprawie, żeby rozwiać wszelkie wątpliwości Rosjan, których działanie niewątpliwie zmierzało ku unieważnieniu wyborów. Polacy obawiali się, że powtórne głosowanie mogłoby radykalnie zmienić skład narodowościowy Rady Miejskiej, w której większość z sześćdziesięciu ośmiu ${ }^{61}$ nowych radnych stanowili Polacy ${ }^{62}$.

Swoje zdanie na temat przeprowadzonych wyborów wyraziła również grupa tzw. demokratów, która poniosła porażkę podczas głosowania. Poszli za przykładem Rosjan i również złożyli skargę do gubernatora, w której przedstawili rzekome trzy nieprawidłowości: brak kontroli policji w trakcie głosowania, przeprowadzenie wyborów w ciągu dwóch dni, a nie trzech, jak ogłoszono wcześniej oraz brak przysięgi składanej przez wyborców (mimo że prawo tego nie wymagało $)^{63} .2$ lipca 1909 r. na posiedzeniu Urzędu Gubernialnego do Spraw Miejskich odrzucono wszystkie te argumenty ${ }^{64}$.

Urząd Gubernialny przychylił się jednak do skargi Rosjan, przez co wybory do Rady Miejskiej w 1909 r. zostały oficjalnie unieważnione, a argumentem za tym przemawiającym był niedostateczny nadzór nad oddawaniem głosów przez wyborców ${ }^{65}$ oraz nieścisłości, które pojawiły się przy podpisywaniu list osób oddających głos, których liczba różniła się od liczby złożonych kulek ${ }^{66}$. Nie ma

57 Kronika Wileńska. Wybory miejskie, „Kurier Litewski”, Wilno, 28 V (10 VI) 1909, nr 118, s. 2.

58 Kronika Wileńska. Dwa zaskarżenia, „Kurier Litewski”, Wilno, 9 (22) VI 1909, nr 127, s. 2.

59 Kronika Wileńska. Wybory miejskie, „Kurier Litewski”, Wilno, 24 VI (7 VII) 1909, nr 140, s. 3; redaktorzy „Kuriera Litewskiego” nazywali ten organ Komisją Gubernialną do Spraw Miejskich.

60 Kronika Wileńska. W sprawie wyborów miejskich, „Kurier Litewski”, Wilno, 17 (30) VI 1909, nr 134, s. 2.

61 Kronika Wileńska. Wyniki wyborów, „Kurier Litewski”, Wilno, 23 V (3 VI) 1909, nr 112, s. 2.

62 Związkowcy i wybory miejskie, „Goniec Wileński”, Wilno, 5 (18) VII 1909, nr 149, s. 1-2.

63 Kronika Wileńska. Wybory miejskie, „Kurier Litewski”, Wilno, 3 (16) VI 1909, nr 122, s. 2.

64 Kronika Wileńska. Wybory miejskie, „Kurier Litewski”, Wilno, 4 (17) VII 1909, nr 148, s. 2.

65 Skasowanie wyborów miejskich, „Goniec Wileński”, Wilno, 11 (24) VII 1909, nr 154, s. 1.

66 Wybory miejskie, „Kurier Litewski”, Wilno, 22 VII (4 VIII) 1909, nr 163, s. 2. 
chyba żadnych wątpliwości, że był to jedynie zabieg polityczny, może nie wymierzony celowo w Polaków, ale na pewno dbający o interes i wpływy narodowości rosyjskiej. Za unieważnieniem wyborów opowiedziało się pięciu z siedmiu członków tego organu: gubernator, podprokurator sądu okręgowego, zarządzający izbą skarbową, marszałek szlachty oraz jeden urzędnik. Przeciwnego zdania był prezydent Węsławski oraz radny Szenfeld. Do końca próbowali przekonać pozostałych członków Urzędu Gubernialnego, że sposób przeprowadzania wyborów nie zmienił się od szesnastu lat, co chcieli udowodnić, przedstawiając całą procedurę $\mathrm{z}$ lat poprzednich. Wydawać by się mogło, że argument prezydenta był nie do podważenia i miał on całkowitą rację, jednak nie przekonało to rosyjskich członków Urzędu Gubernialnego ${ }^{67}$.

Zarząd zobowiązany był do wyznaczenia nowego terminu wyborów, jednak prezydent Węsławski wolał poczekać na powrót wszystkich radnych, którzy wyjechali na urlop ${ }^{68}$. Zasugerował, że głosowanie może się odbyć pod koniec sierpnia albo na początku września, a Zarząd rozważał również możliwość zmiany sposobu oddawania głosów, aby nie powtórzyły się skargi wyborców rosyjskich. Dlatego zaproponowano rezygnację z balotażu i pozostanie przy tradycyjnej formie głosowania za pomocą kartek ${ }^{69}$. To z pewnością przyspieszyłoby cały proces i uchroniło przed późniejszymi aktami sprzeciwu. Instrukcja przeprowadzania wyborów była przygotowywana przez Zarząd, a następnie zatwierdzana przez Radę Miejską i gubernatora ${ }^{70}$.

Ponowne wybory w 1909 r. odbyć się miały 9 września. Głosować miano przy pomocy kartek, o czym poinformowano opinię publiczną ${ }^{71}$, a ponadto każdy wyborca otrzymał nową instrukcję wyborczą ${ }^{72}$. Oprócz tego oddanie głosu miało ułatwić rozwiązanie się tzw. komitetu demokratycznego, który tym razem zrezygnował z wystawiania swoich kandydatów, aby nie rozbijać głosów wyborców. Pod koniec sierpnia natomiast listę przedstawił komitet „bezpartyjny”, uznając, że dzięki jednej liście „polskiej” można uniknąć niepotrzebnych konfliktów wewnętrznych, co pomoże wyborcom w podjęciu decyzji. W odezwie bloku bezpartyjnego do obywateli Wilna jego członkowie zwrócili uwagę, że pojawiła się lista fałszywa, którą ktoś wysyłał do wyborców, podszywając się pod ich komitet ${ }^{73}$.

67 Skasowanie wyborów miejskich, „Goniec Wileński”, Wilno, 11 (24) VII 1909, nr 154, s. 1.

68 Kronika Wileńska. W sprawie wyborów miejskich, „Kurier Litewski”, Wilno, 15 (28) VII 1909, nr 157, s. 2.

69 Wybory miejskie, „Kurier Litewski”, Wilno, 22 VII (4 VIII) 1909, nr 163, s. 2-3.

70 Kronika Wileńska. Wybory miejskie, „Kurier Litewski”, Wilno, 23 VII (5 VIII) 1909, nr 164, s. 2.

71 Kronika Wileńska. Wybory miejskie, „Kurier Litewski”, Wilno, 28 VII (10 VIII) 1909, nr 168, s. 2.

72 Kronika Wileńska. Wybory miejskie, „Kurier Litewski”, Wilno, 6 (19) VIII 1909, nr 176, s. 2.

73 Odezwa do wyborców miejskich, „Goniec Wileński”, Wilno, 8 (21) IX 1909, nr 203, s. 1. 
Termin ponownych wyborów zbliżał się nieuchronnie i Zarząd Miejski w połowie sierpnia rozpoczął do niego przygotowania. W pierwszej kolejności skupiono się na sprawdzeniu listy wyborców, którzy spełniają kryteria cenzusu majątkowego, co mogło ulec zmianie po poprzednich wyborach ${ }^{74}$. Następnie przystąpiono do sporządzenia powiadomień dla wyborców i blankietów wyborczych $^{75}$. W informacji rozesłanej do wyborców poinformowano o terminie głosowania, który przypadał na 9 września 1909 r., w godzinach od dziesiątej do dwudziestej, w sali miejskiej nr 10, gdzie miało odbyć się osobiste składanie kartek z podaniem kandydatów na radnych. Miano ich powołać w liczbie siedemdziesięciu siedmiu i szesnastu kandydatów (zastępców). Zastrzeżono, że na kartkach może się znaleźć tylko nazwisko, a gdyby pojawiło się coś ponadto, w takim przypadku głos byłby unieważniony. Co ciekawe, dopuszczono możliwość oddawania głosów nie na specjalnych blankietach, przygotowanych przez Zarząd, ale na zwykłym papierze ${ }^{76}$, co $\mathrm{z}$ wiadomych względów nie przyczyniało się do zabezpieczenia przed próbami sfałszowania elekcji.

Powtórzone wybory odbyły się zgodnie z planem - o godzinie dziesiątej prezydent miasta Michał Węsławski przywitał wyborców, a sekretarz Rady Miejskiej odczytał odpowiednie przepisy prawa odnoszące się do wyborów miejskich. Zgodnie z procedurą komisja wyborcza i wyborcy sprawdzili skrzynię do składania głosów, którą następnie opieczętowano. Ponieważ nie wniesiono żadnych uwag, rozpoczęto oddawanie kartek z nazwiskami kandydatów na radnych. Kolejnego dnia odbyło się liczenie głosów, co zajęło komisji cały dzień, od godziny dziesiątej do dwudziestej drugiej ${ }^{77}$. Obliczono, że w urnie znalazły się czterysta trzy głosy ${ }^{78}$, po których sprawdzeniu ogłoszono wynik wyborów. Zgodnie z zapowiedzią wybrano siedemdziesięciu siedmiu radnych i szesnastu kandydatów oraz zauważono, że gros spośród tych osób stanowią przedstawiciele komitetu bezpartyjnego, których nazwiska pojawiły się na liście wyborczej podczas majowego głosowania ${ }^{79}$.

Zarząd przedłożył gubernatorowi do zatwierdzenia całą procedurę wyborczą, jaką zastosowano podczas powtórnych wyborów oraz poprosił o zwrócenie się do ministra spraw wewnętrznych z prośbą o określenie liczby radnych narodowości żydowskiej. Upatrzono już kilku kandydatów, mogących pełnić tę funkcję $\mathrm{i}$ odpowiednią listę $\mathrm{z}$ nazwiskami złożono gubernatorowi ${ }^{80}$. Do gubernatora nie wpłynęła żadna skarga na przeprowadzone wybory, więc przystąpiono do spo-

74 Kronika Wileńska. Wybory miejskie, „Kurier Litewski”, Wilno, 12 (25) VIII 1909, nr 181, s. 2.

75 Kronika Wileńska. Wybory miejskie, „Kurier Litewski”, Wilno, 22 VIII (4 IX) 1909, nr 189, s. 2.

76 Kronika Wileńska. Wybory miejskie, „Kurier Litewski”, Wilno, 26 VIII (8 IX) 1909, nr 152, s. 2.

77 Kronika Wileńska. Wybory miejskie, „Kurier Litewski”, Wilno, 10 (23) IX 1909, nr 204, s. 2.

78 Kronika Wileńska. Wybory miejskie, „Kurier Litewski”, Wilno, 11 (24) IX 1909, nr 205, s. 2.

79 Kronika Wileńska. Wybory miejskie, „Kurier Litewski”, Wilno, 12 (25) IX 1909, nr 206, s. 2.

80 Kronika Wileńska. Wybory miejskie, „Kurier Litewski”, Wilno, 17 (30) IX 1909, nr 210, s. 2. 
rządzania listy nowych radnych, aby opublikować ją na łamach „Gubiernskich Wiedomostiach”. Zarząd Miejski zakładał, że pierwsze posiedzenie nowej rady mogłoby się odbyć 20 października 1909 r., podczas którego wybranoby prezydenta miasta, dwóch członków Zarządu oraz sekretarza Rady Miejskiej ${ }^{81}$, ale jeszcze w październiku datę tę zmieniono na 5 listopada ${ }^{82}$. Kandydatura Michała Węsławskiego na prezydenta po raz kolejny nie budziła żadnych wątpliwości.

Przebywający w Petersburgu prezydent poinformował mieszkańców Wilna, że minister spraw wewnętrznych określił liczbę radnych - Żydów, na siedem osób, co oznaczało, że tyle samo wcześniej wybranych radnych stanie się kandydatami. Oczywiście decydowała o tym ilość zdobytych głosów, jednak w przypadku otrzymania tej samej liczby wyboru dokonywano na podstawie losowania ${ }^{83}$. Skład narodowościowy radnych wyglądał następująco: Polaków pięćdziesięciu sześciu, Rosjan - dziewięciu, Żydów - siedmiu, Litwinów - trzech, jeden Niemiec i jeden Karaim. Osób, które wcześniej nie pełniły tej funkcji było w sumie dwadzieścia dziewięć ${ }^{84}$.

Ze względu na zbliżający się termin pierwszej sesji nowej Rady Miejskiej przyszli radni 24 października zorganizowali spotkanie zapoznawcze, podczas którego debatowali nad wyborem składu Zarządu Miejskiego ${ }^{85}$. Węsławski otrzymał zgodę gubernatora na zwołanie posiedzenia nadzwyczajnego Rady Miejskiej na 30 października, podczas którego miano wybrać członków Zarządu i ustalić ich honoraria ${ }^{86}$.

Zgodnie z tradycją pierwszą sesję otworzył prezydent miasta, który po powitaniu radnych i gości przeszedł do wskazania podstawowych zadań, jakie pojawią się przed Radą i od wykonania których zależy rozwój Wilna. W swoim przemówieniu wskazał, że konieczna jest zmiana opodatkowania nieruchomości, reforma szkolnictwa i powołanie przedsiębiorstw miejskich. W dalszej kolejności przystąpiono do wyboru prezydenta, co było jedynie formalnością, bo jednomyślny wynik nikogo nie zdziwił. Ponadto wybrano członków dwóch komisji miejskich: budżetowej oraz specjalnej, powołanej do realizacji pożyczki ${ }^{87}$.

Niewątpliwie wybory miejskie w 1909 r. przyniosły wiele niespodzianek mieszkańcom Wilna, jednak trzeba przyznać, że, mimo opozycyjnej działalności grupy rosyjskiej, udało się zrealizować zamierzony cel i w konsekwencji Polacy zdobyli zdecydowaną większość w składzie Rady Miejskiej. Był to nie tylko

81 Kronika Wileńska. Wybory miejskie, „Kurier Litewski”, Wilno, 22 IX (5 X) 1909, nr 214, s. 2.

82 Kronika Wileńska. Wybory miejskie, „Kurier Litewski”, Wilno, 15 (23) X 1909, nr 234, s. 2.

83 Kronika Wileńska. Wybory miejskie, „Kurier Litewski”, Wilno, 15 (23) X 1909, nr 234, s. 2.

84 Kronika Wileńska. Wybory miejskie, „Kurier Litewski”, Wilno, 16 (29) X 1909, nr 235, s. 2.

85 Kronika Wileńska. Nowa Rada miejska, „Kurier Litewski”, Wilno, 24 X (6 XI) 1909, nr 241, s. 2.

86 Kronika Wileńska. Posiedzenie Rady miejskiej, „Kurier Litewski”, Wilno, 29 X (11 XI) 1909, nr 246, s. 2.

87 Z. R., W Radzie miejskiej, „Kurier Litewski”, Wilno, 1 (14) XI 1909, nr 248, s. 2. 
sukces radnych, którzy mogli pełnić zaszczytną funkcję, ale przede wszystkim polskich mieszkańców Wilna, którzy z pewnością mieli poczucie, że ktoś będzie dbał o ich interes.

Należy przyznać, że miasto w trakcie czteroletniej kadencji Rady Miejskiej zrobiło znaczny postęp w rozwoju cywilizacyjnym. Mimo że posiadało ciągle głównie zabudowę drewnianą, bo było to aż $66 \%$ wszystkich nieruchomości ${ }^{88}$, rozpoczęto poważne inwestycje. Na pierwszy plan wysunęły się te związane z kanalizacją i wodociągami, których tak bardzo brakowało mieszkańcom miasta znad Wilii. Faktem było, że Zarząd nie posiadał odpowiednich środków do wykonania tych projektów i musiał zaciągnąć pożyczkę bankową ${ }^{89}$. Podobnie rzecz się miała w sprawie miejskiej elektrowni oraz tramwajów, jednak każdy zdawał sobie sprawę, że są to inwestycje konieczne i pewne, które przyniosą daleko idące korzyści w dłuższej perspektywie czasu, dlatego przystąpiono do odpowiednich prac. Szczególne miejsce w debacie publicznej znalazła sprawa uniwersytetu wileńskiego, symbolu odrodzenia życia kulturowego i naukowego na obszarze Wileńszczyzny. Zarząd Miejski powołał nawet specjalną komisję do spraw otwarcia wyższego zakładu naukowego już w 1908 r. ${ }^{90}$, której zadaniem było opracowanie odpowiedniej dokumentacji i przygotowanie planu działań, zbliżających do realizacji projektu.

W 1913 r. działania Rady Miejskiej ewidentnie zostały zintensyfikowane. Zarząd Miejski zdecydował już w maju, że odpowiednim terminem do przeprowadzenia wyborów będzie październik, o czym poinformował wilnian ${ }^{91}$. W celu uniknięcia skarg, jakie pojawily się przy poprzednich wyborach, postanowiono ograniczyć się do głosowania za pomocą kartek, co stanowiło o wiele prostszą formę wyboru przyszłych radnych ${ }^{92}$. Przygotowano również listę tysiąca trzystu osiemdziesięciu trzech osób i instytucji, które mogły wziąć udział w głosowaniu, z zastrzeżeniem, że prawa tego mogło być pozbawionych 10 obywateli, którzy zalegali z opłatami podatków ${ }^{93}$. Tak przygotowaną listę przesłano do zaaprobowania przez gubernatora, który zgodził się z Zarządem, aby ją opublikować,

88 K. Niedziałkowski, Biedne miasto. Trochę cyfr ze statystyki Wilna, „Przegląd Wileński”, Wilno, 8 (21) VI 1913, nr 22-23, s. 8-9.

89 Pożyczka na elektrownię, „Kurier Litewski”, Wilno, 21 IV (4 V) 1913, nr 90, s. 2; patrz też: Woda w wodociagach, „Kurier Litewski”, Wilno, 31 III (13 IV) 1913, nr 74, s. 2.

90 Z Wilna. Sprawa uniwersytetu w Wilnie, „Gazeta Codzienna”, Wilno, 2 (15) VIII 1913, nr 199, s. 3; patrz też: D. Szpoper, P. Dąbrowski, Idea utworzenia wyższego zakładu naukowego w Wilnie na początku XX wieku, [w:] Rola oświaty i szkolnictwa w procesie kształtowania się świadomości narodowej na pograniczu polsko-litewsko-białoruskim, red. W. Śleszyński, Białystok 2007, s. 105.

91 Wiadomości bieżace. Sprawy miejskie. Wybory radnych miejskich..., „Kurier Litewski”, Wilno, 4 (17) V 1913, nr 101, s. 2.

92 Wiadomości bieżące. Sprawy miejskie. Przed wyborami do Rady miejskiej, „Kurier Litewski”, Wilno, 12 (25) VI 1913, nr 132, s. 2.

93 Z Wilna. Wybory miejskie, „Gazeta Codzienna”, 3 (16) VIII 1913, nr 200, s. 3. 
dając tym samym dwutygodniowy termin na składanie skarg na ewentualne błę$\mathrm{dy}^{94}$. Gubernator przychylił się również do wniosku prezydenta Węsławskiego i zatwierdził termin wyborów na 24 października ${ }^{95}$.

Kampania wyborcza ruszyła już latem 1913 r., co można było zauważyć po zawiązaniu się komitetu przedwyborczego, w którego skład weszły dwadzieścia cztery osoby, reprezentujące różne poglądy polityczne i dzielnice miasta. Celem komitetu było zwrócenie uwagi obywatelom, czym powinni się kierować, oddając głos w wyborach oraz czym musiała zająć się przyszła Rada Miejska. Po pierwsze, przypomniano wyborcom, aby nie dali się wciągnąć $\mathrm{w}$ grę polityczną, a raczej zdecydowali się na kandydata, który faktycznie reprezentuje dbałość o interes miasta i jego obywateli. Po drugie, przedstawiono szereg zadań, jakimi powinni zająć się przyszli radni. Chodziło przede wszystkim o kontynuowanie prac związanych $\mathrm{z}$ przeprowadzeniem linii tramwajowej, poszerzeniem sieci kanalizacji i wodociągów oraz zadbanie o peryferia miasta, które do tej pory były pomijane w poważniejszych inwestycjach. Komitet zwrócił także uwagę na problem powszechnej drożyzny artykułów spożywczych i ciężkiej sytuacji ludzi ubogich. Zaproponowano tym samym utworzenie w przyszłości domów noclegowych, giełd pracy, piekarni miejskiej, wprowadzenie nieodpłatnej edukacji początkowej i dostępu do porad prawnych ${ }^{96}$.

Wyrazem tego apelu było ukonstytuowanie się bezpartyjnego komitetu wyborczego, powołanego przez wyborców miejskich. Była to jedyna taka organizacja, której celem było przygotowanie listy kandydatów o odmiennych przekonaniach politycznych i występujących w interesie różnych warstw społecznych. Gwarantowało to neutralność polityczną, co w ówczesnym stadium rozwoju miasta dawało szansę na szybkie zakończenie prac budowlanych. Nie było wtedy miejsca dla różnic programowych, oddalających radnych od wspólnego celu, jakim powinien być rozwój cywilizacyjny Wilna. Komitet bezpartyjny wykonał swoje zadanie i na początku października opracował listę z dziewięćdziesięcioma sześcioma nazwiskami kandydatów na radnych, która następnie miała być wysłana do wszystkich tysiąca trzystu sześćdziesięciu dziewięciu ${ }^{97}$ wyborców ${ }^{98}$. Na podstawie procentowego stosunku narodowości komitet zaproponował, że w sytuacji, gdy Rada miałaby się składać z osiemdziesięciu osób, to trzynaście miejsc zarezerwowanych mogłoby być dla Rosjan

94 Wiadomości bieżące. Sprawy miejskie. Przed wyborami do Rady miejskiej, „Kurier Litewski”, Wilno, $30 \mathrm{~V}$ (12 VI) 1913, nr 122, s. 2.

95 Wiadomości bieżące. Sprawy miejskie. Wybory do Rady miejskiej, „Kurier Litewski”, Wilno, 28 VIII (10 IX) 1913, nr 195, s. 2.

96 Przed wyborami do Rady miejskiej, „Kurier Litewski”, Wilno, 6 (19) VII 1913, nr 151, s. 2; patrz też: Urbanus [sygn. nierozwiązana], Przed wyborami miejskimi, „Przegląd Wileński”, Wilno, 3 (16) VIII 1913, nr 30-31, s. 12-13.

97 Wiadomości bieżące. Ilość wyborców, „Kurier Litewski”, Wilno, 12 (25) IX 1913, nr 208, s. 2.

98 Wybory do Rady miejskiej, „Gazeta Codzienna”, Wilno, 13 (26) X 1913, nr 269, s. 1-2. 
i osiem dla Żydów, co dawałoby pięćdziesięciu dziewięciu radnych narodowości polskiej ${ }^{99}$.

Dzień 24 października zbliżał się nieuchronnie i na początku miesiąca z pewnością dało się odczuć przedwyborczą atmosferę. Wtedy po raz pierwszy w prasie pojawiły się reklamy komitetów wyborczych, których powstało aż pięćc ${ }^{100}$. Oczywiście każda $\mathrm{z}$ tych grup zaproponowała swoją listę kandydatów. Do najbardziej liczących się trzeba zaliczyć, wspomniany wyżej, komitet bezpartyjny, którego lista nazwana została białą (od koloru papieru), komitet uświadomionych wyborców z listą błękitną oraz komitet demokratycznych wyborców $\mathrm{z}$ listą szarą ${ }^{101}$.

Wybory w 1913 r. odbyły się zgodnie z planem 24 października i trwały od godziny dziesiątej do dwudziestej w Sali Miejskiej przy ulicy Ostrobramskiej 10. Wyborców upomniano, że listy kandydatów na radnych należało składać w języku rosyjskim, z podaniem ich pełnych imion i nazwisk oraz imion ojców. Niedopuszczalne były przekreślenia i poprawki, co w przeciwnym razie skutkowało unieważnieniem głosu. Ponadto każda kartka, przed wrzuceniem do urny, musiała być włożona do czystej koperty, którą wyborca był zobowiązany osobiście zakleićc ${ }^{102}$. W korytarzu lokalu wyborczego przez cały dzień trwała agitacja. Wśród zebranego tłumu krążyły wydrukowane już listy kandydatów, których de facto było aż osiem. Pojawiało się też wiele kartek fałszywych, imitujących kolorem oryginały, co wprowadzało niemały zamęt ${ }^{103}$.

Ze względu na zwiększoną liczbę wyborców, obliczanie głosów zabrało więcej czasu niż w poprzednich wyborach i zakończyło się dopiero 26 października o godzinie dwudziestej pierwszej. Ku zadowoleniu większości wygrali kandydaci zaproponowani przez komitet bezpartyjny z listy „białej”, zdobywając osiemdziesiąt mandatów w Radzie Miejskiej i szesnaście stanowisk kandydackich ${ }^{104}$. Prezydent Węsławski otrzymał aż $508^{105}$ głosów na $517^{106}$ wyborców, którzy wrzucili swoje kartki do urny. Tylko czterdziestu jeden radnych z poprzedniej kadencji kontynuowało ją dalej. Obywatele Wilna powierzyli zaszczytną funk-

99 Wiadomości bieżące. Przed wyborami do Rady Miejskiej, „Kurier Litewski”, Wilno, 22 IX (5 X) 1913, nr 217, s. 2.

100 Przed wyborami do Rady Miejskiej, Z Wilna, „Gazeta Codzienna”, Wilno, 18 (31) X 1913, nr 274, s. 2.

101 Wobec wyborów do Rady miejskiej, „Gazeta Codzienna”, Wilno, 20 X (2 XI) 1913, nr 276, s. 1-2; patrz też: Wybory miejskie, „Gazeta Codzienna”, Wilno, 23 X (5 XI) 1913, nr 279, s. 1.

102 Wiadomości bieżace. Sprawy miejskie. Wybory do Rady miejskiej, „Kurier Litewski”, Wilno, 24 X (6 XI) 1913, nr 244, s. 2.

103 Wiadomości bieżace. Sprawy miejskie. Wybory do Rady miejskiej, „Kurier Litewski”, Wilno, 25 X (7 XI) 1913, nr 245, s. 2.

104 Wybory do Rady miejskiej, „Gazeta Codzienna”, Wilno, 27 X (9 XI) 1913, nr 283, s. 2.

105 Wynik wyborów do Rady miejskiej, „Kurier Litewski”, Wilno, 27 X (9 XI) 1913, nr 247, s. 2.

106 Wybory do Rady miejskiej, „Kurier Litewski”, Wilno, 26 X (8 XI) 1913, nr 246, s. 2. 
cję radnego szesnastu urzędnikom instytucji prywatnych, trzynastu inżynierom, ośmiu prawnikom, siedmiu lekarzom, sześciu pedagogom i w takiej samej liczbie handlowcom, czterem urzędnikom rządowym, jednemu dentyście, aptekarzowi, przemysłowcowi, rzemieślnikowi i ośmiu rentierom ${ }^{107}$. Aby zatwierdzić wynik wyborów Urząd Gubernialny do Spraw Miejskich musiał poczekać na rozporządzenie Ministra Spraw Wewnętrznych w sprawie liczby radnych - Żydów ${ }^{108}$. Ze względu na fakt, że minister zwlekał z decyzją, pierwsze posiedzenie nowej Rady Miejskiej i wybór członków Zarządu odbyło się dopiero w styczniu 1914 r. ${ }^{109}$

Niecałe dziewięć lat, jakie dzieliło wybory z 1913 r. od pierwszych, przeprowadzonych w 1905 r., można nazwać „polskimi latami” zarządzania Wilnem. Trzeba zauważyć, że mimo naturalnych różnic, dzielących Polaków, ale też odmienności, wynikających z wielokulturowości tego miasta, Rada Miejska i Zarząd systematycznie wprowadzały Wilno w wiek XX - czas rozwoju cywilizacyjnego. Tę zasługę można upatrywać w składzie Rady Miejskiej, w której zasiadali nie politycy, ale przedstawiciele wielu szanowanych zawodów, którzy mogli wykorzystać swoją wiedzę i doświadczenie w pracy na rzecz swojej małej ojczyzny. Dziewięciolecie polskich rządów to przede wszystkim postęp w zakresie poprawy sytuacji sanitarnej i transportowej, za czym kryje się budowa kanalizacji i wodociągów oraz pierwszych torów tramwajowych. Był to też okres rozwoju polskiego życia kulturalnego na Wileńszczyźnie, które skupiło się przede wszystkim w teatrze. W 1913 r. mieszkańcy Wilna doczekali się nowego gmachu Teatru Polskiego, kolejnego symbolu przynależności narodowej.

Funkcjonowanie samorządu miejskiego i wpływy polskie w działalności politycznej i kulturowej zmieniły się we wrześniu 1915 r., kiedy do miasta wkroczyły wojska niemieckie, rozpoczynając jego trzyletnią okupację. Funkcjonowanie magistratu dopasowano do wzorców niemieckich, podobnie stało się z Radą Miejską i Zarządem. Ta pierwsza została przemianowana na przyboczne Rady Miejskie, a Zarząd Miejski został powiększony o 6 osób i zyskał nazwę Rady Dodatkowej, działającej przy niemieckim nadburmistrzu ${ }^{110}$.

107 Wiadomości bieżące. Sprawy miejskie. Po wyborach do Rady miejskiej, „Kurier Litewski”, Wilno, $30 \mathrm{X}$ (12 XI) 1913, nr 249, s. 2.

108 Wiadomości bieżace. Sprawy miejskie. Nowa Rada miejska, „Kurier Litewski”, Wilno, 28 XI (11 XII) 1913 , nr 273, s. 2.

109 Z Wilna. Z Rady miejskiej, „Gazeta Codzienna”, Wilno, 28 XI (11 XII) 1913, nr 314, s. 3.

110 P. Dąbrowski, op. cit., s. 79-80. 


\section{Wykaz źródeł i opracowań}

\section{Czasopisma}

„Gazeta Codzienna”, Wilno, rocznik: 1913 (Biblioteka Litewskiej Akademii Nauk im. Wróblewskich w Wilnie).

„Goniec Wileński”, Wilno, rocznik: 1909 (Biblioteka Litewskiej Akademii Nauk im. Wróblewskich w Wilnie).

„Kurier Litewski”, Wilno, roczniki: 1905, 1909, 1913 (Biblioteka Litewskiej Akademii Nauk im. Wróblewskich w Wilnie).

„Przegląd Wileński”, Wilno, rocznik: 1913 (Biblioteka Litewskiej Akademii Nauk im. Wróblewskich w Wilnie).

„Słowo”, Wilno, rocznik: 1905 (Biblioteka Litewskiej Akademii Nauk im. Wróblewskich w Wilnie).

\section{Opracowania}

Bazylow L., Dzieje Rosji 1801-1917, Warszawa 1977.

Bazylow L., Wieczorkiewicz P., Historia Rosji, Wrocław 2005.

Czistiakow O. J., Nowickaja T. E., Gorodowoje położenije wysoczajsze utwerżdennoje 16 (28) ijunija 1870 goda, [w:] Reformy Aleksandra II, Moskwa 1997.

Dąbrowski P., Narodowa Demokracja byłego Wielkiego Księstwa Litewskiego. Studium z zakresu myśli politycznej i działalności obozu narodowego na ziemiach litewsko-białoruskich w latach 1897-1918, Kraków 2010.

Dąbrowski P., Siła w kulturze, jedność w narodzie. Wileńska działalność społeczno-polityczna Michała, Witolda i Emilii Węsławskich w końcu XIX wieku i pierwszej połowie XX stulecia (do 1930 roku), Gdańsk 2011.

Jaworski I., Zarys dziejów Wilna, Wilno 1929.

Sobczak J., Mikołaj II - ostatni car Rosji, Warszawa 2009.

Szpoper D., Dąbrowski P., Idea utworzenia wyższego zakładu naukowego w Wilnie na początku XX wieku, [w:] Rola oświaty i szkolnictwa w procesie kształtowania się świadomości narodowej na pograniczu polsko-litewsko-białoruskim, red. W. Śleszyński, Białystok 2007. 